\title{
Body weight and the prevalence of chronic diseases
}

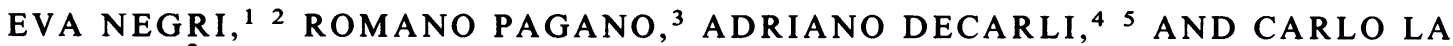 \\ VECCHIA ${ }^{2}$
}

From Consorzio Interuniversitario Lombardo per l'Elaborazione Automatica, ${ }^{\prime} 20090$ Segrate, Milan, Italy; Istituto di Ricerche Farmacologiche "Mario Negri", 2 via Eritrea, 62-20157 Milan, Italy; Istituto Centrale di Statistica, ${ }^{3} 00100$ Rome, Italy; Istituto di Biometria e Statistica Medica, ${ }^{4}$ Università di Milano, Istituto Nazionale Tumori, 20133 Milan; and Istituto di Statistica e Ricerca Operativa, ${ }^{5}$ Università di Trento, 38100 Trento, Italy.

SUMMARY The relation between body mass index and prevalence of 17 chronic diseases or groups of diseases was analysed using data from the 1983 Italian National Health Survey, based on a sample of 72284 individuals aged 15 or over randomly selected within strata of geographical area, size of place of residence and of household in order to be representative of the whole Italian population. The prevalence of diabetes was directly and strongly related to body weight (age-adjusted relative risk estimates being 1.5 for overweight and 2.7 for obese men compared with normal weight individuals; 1.6 and 2.4 for overweight and obese women). Other conditions directly related to self-reported measures of body weight were hypertension (relative risk $=1.7$ for obese men and 1.9 for women), myocardial infarction (relative risk $=1.5$ for obese men, 1.6 for women), other heart diseases (relative risk $=1.7$ for obese men, 1.5 for women), haemorrhoids or varices (relative risk $=1.2$ for obese men, 1.5 for women), cholelithiasis (relative risk $=1.2$ for obese men, 1.4 for women), urolithiasis and arthritis. Chronic respiratory disorders showed a U-shaped relation to measures of body weight, since their prevalence was elevated in both under- and over-weight individuals. Anaemias and gastroduodenal ulcer showed an inverse relation to body weight, whereas no association was apparent with allergy, liver cirrhosis, and psychiatric or neurological disorders. Allowance for the two major identified covariates (education and smoking) failed to explain the observed variations between measures of body weight and disease, while separate inspection of various strata of age indicated that for most diseases the elevated risks of obesity were higher in younger age and decreased steadily with advancing age. Thus, the results of this national survey indicate that overweight has a widespread and substantial impact not only on mortality but also on morbidity from different chronic conditions.

There is consistent evidence that body weight is a correlate of mortality. The lowest mortality is repeatedly observed among individuals close to the average weight, and mortality ratios increase substantially in both underweight $(<80 \%$ of the average weight) and overweight subjects, ${ }^{1-4}$ being over $50 \%$ elevated among obese individuals $(>130 \%$ of the ideal weight). The major causes of the increased mortality among the overweight and obese are diabetes, cardio- and cerebro-vascular diseases, digestive diseases, and some types of cancers (gallbladder, breast, endometrium, and prostate). ${ }^{5}$

Less information is available on the relation between body weight and prevalence of diseases. The presence of data on height, weight, and prevalence of major chronic conditions within the 1983 National Health Survey conducted by the Italian Central
Institute of Statistics gave the opportunity to examine the relation between body weight and frequency of disease in a large sample representative of the whole Italian population.

\section{Materials and methods}

THE 1983 NATIONAL HEALTH SURVEY The Survey was organised and conducted by the Italian Central Institute of Statistics (ISTAT) during the week of 28 November to 3 December $1983 .^{6}$ The general design of this investigation has already been described. $^{7}$ Briefly, interviews were arranged and conducted by civil servants appointed by each municipality included in the study on a sample of 31025 households (for a total of 89753 individuals) randomly chosen within strata of geographical area 
(region), size of the municipality, and size of the household in order to be representative of the whole Italian population. Impossibility of tracing or refusal of the interview led to the substitution of 2058 households, thus giving an overall participation rate for the original sample of $\mathbf{9 3 . 4 \%}$. Proxy interviews were permitted for members not present in the house ( $8.3 \%$ of the sample considered).

Information was collected on sociodemographic characteristics including self-reported height and weight; current health status; prevalence of 19 chronic diseases or groups of diseases (including major cardiovascular conditions, respiratory and digestive tract disorders, renal and urinary tract diseases, arthritis, and nervous disorders); health service utilisation during the month (for outpatient procedures) or the year (for inpatient procedures) preceding the interview; smoking habits; and coffee and alcohol consumption.

We obtained copies of the original computer tape from the Central Institute of Statistics including all available information for each individual. Subjects below age 15 were not considered, thus leaving a total of 34787 men and 37497 women.

DATA ANALYSIS AND CONTROL OF CONFOUNDING

An index of body mass was computed according to the standard Quetelet's formula (weight, $\mathrm{kg} /$ height, $\mathrm{m}^{2}$ ) and $a$ priori subdivided into four levels: $<20$, underweight; 20-24.9 normal; 25-29.9, overweight; $\geq 30$ obese. The Quetelet's index is essentially an indicator of weight, and it is uncorrelated to height, ${ }^{8}$

We computed the odds ratios (as estimators of relative risk, RR) for the prevalence of selected diseases, together with their $95 \%$ approximate confidence intervals ${ }^{9}$ according to body mass index from data stratified for age in decades by means of the usual Mantel-Haenszel procedure. ${ }^{10}$ It is known that social class and smoking habits are correlates of body weight, although in this dataset the relation between smoking and body weight was rather complex (for instance, heavy smokers were more frequently overweight than moderate smokers), and heterogeneous in the two sexes. ${ }^{11}$ Further allowance (separately or simultaneously) for these covariates, however, did not materially modify any of the risk estimates. Thus, the relative risks adjusted for age only were chosen for presentation unless otherwise specified.

\section{Results}

The percent distribution of the 34787 men and 37497 women interviewed according to estimated body mass index is shown in table 1 . Overall, $51 \%$ of the subjects

Table 1 Percent distribution of 72,284 subjects in the 1983 Italian National Health Survey according to body mass index, sex, age group, educational attainment, and smoking habits.

\begin{tabular}{|c|c|c|c|c|c|c|}
\hline & \multirow{2}{*}{ Sex } & \multicolumn{4}{|c|}{ Percent distribution of body mass index $\left(\mathrm{kg} / \mathrm{m}^{2}\right)$} & \multirow{2}{*}{ No. of subjects } \\
\hline & & $<20$ & $20-24 \cdot 9$ & $25-29.9$ & $\geqslant 30$ & \\
\hline \multicolumn{7}{|l|}{ Age group } \\
\hline $15-44$ & $\begin{array}{l}\mathbf{M} \\
\mathbf{F}\end{array}$ & $\begin{array}{r}9 \cdot 3 \\
28 \cdot 1\end{array}$ & $\begin{array}{l}59 \cdot 1 \\
55 \cdot 9\end{array}$ & $\begin{array}{l}26 \cdot 8 \\
12 \cdot 0\end{array}$ & $\begin{array}{l}4 \cdot 8 \\
3.9\end{array}$ & $\begin{array}{l}18714 \\
19099\end{array}$ \\
\hline $45-64$ & $\begin{array}{l}\mathbf{M} \\
\mathbf{F}\end{array}$ & $\begin{array}{l}3 \cdot 9 \\
9 \cdot 2\end{array}$ & $\begin{array}{l}41 \cdot 7 \\
48 \cdot 3\end{array}$ & $\begin{array}{l}44 \cdot 5 \\
31 \cdot 4\end{array}$ & $\begin{array}{r}9.9 \\
11 \cdot 1\end{array}$ & $\begin{array}{l}10933 \\
11710\end{array}$ \\
\hline$\geqslant 65$ & $\begin{array}{l}\mathbf{M} \\
\mathbf{F}\end{array}$ & $\begin{array}{r}8 \cdot 2 \\
14 \cdot 7\end{array}$ & $\begin{array}{l}44 \cdot 0 \\
43 \cdot 2\end{array}$ & $\begin{array}{l}38 \cdot 3 \\
30 \cdot 3\end{array}$ & $\begin{array}{r}9.5 \\
11.7\end{array}$ & $\begin{array}{l}5140 \\
6688\end{array}$ \\
\hline \multicolumn{7}{|l|}{ Educational attainment ${ }^{\dagger}$} \\
\hline Primary school or less & $\begin{array}{l}\mathbf{M} \\
\mathbf{F}\end{array}$ & $\begin{array}{r}5.1 \\
11.5\end{array}$ & $\begin{array}{l}42 \cdot 4 \\
46 \cdot 5\end{array}$ & $\begin{array}{l}42 \cdot 6 \\
30 \cdot 8\end{array}$ & $\begin{array}{r}9.9 \\
11 \cdot 3\end{array}$ & $\begin{array}{l}15927 \\
20381\end{array}$ \\
\hline Middle school & $\begin{array}{l}\mathbf{M} \\
\mathbf{F}\end{array}$ & $\begin{array}{r}4 \cdot 6 \\
18 \cdot 4\end{array}$ & $\begin{array}{l}50 \cdot 0 \\
60 \cdot 4\end{array}$ & $\begin{array}{l}39 \cdot 5 \\
17.0\end{array}$ & $\begin{array}{l}6 \cdot 0 \\
4 \cdot 3\end{array}$ & $\begin{array}{r}10705 \\
9802\end{array}$ \\
\hline High school or university & $\begin{array}{l}\mathbf{M} \\
\mathbf{F}\end{array}$ & $\begin{array}{r}4 \cdot 5 \\
24 \cdot 7\end{array}$ & $\begin{array}{l}57 \cdot 1 \\
60 \cdot 5\end{array}$ & $\begin{array}{l}33.5 \\
11.8\end{array}$ & $\begin{array}{l}5 \cdot 0 \\
3 \cdot 1\end{array}$ & $\begin{array}{l}7801 \\
6901\end{array}$ \\
\hline \multicolumn{7}{|l|}{ Smoking habits } \\
\hline Never smokers & $\begin{array}{l}\mathbf{M} \\
\mathbf{F}\end{array}$ & $\begin{array}{r}9.9 \\
19.0\end{array}$ & $\begin{array}{l}53 \cdot 1 \\
50 \cdot 1\end{array}$ & $\begin{array}{l}30 \cdot 4 \\
22 \cdot 6\end{array}$ & $\begin{array}{l}6 \cdot 6 \\
8 \cdot 3\end{array}$ & $\begin{array}{l}14144 \\
29779\end{array}$ \\
\hline Ex smokers & $\begin{array}{l}\mathbf{M} \\
\mathbf{F}\end{array}$ & $\begin{array}{r}4.0 \\
15 \cdot 6\end{array}$ & $\begin{array}{l}41 \cdot 1 \\
56 \cdot 5\end{array}$ & $\begin{array}{l}45 \cdot 1 \\
21 \cdot 3\end{array}$ & $\begin{array}{l}9.8 \\
6.6\end{array}$ & $\begin{array}{r}4815 \\
921\end{array}$ \\
\hline Smokers & $\begin{array}{l}\mathbf{M} \\
\mathbf{F}\end{array}$ & $\begin{array}{r}6 \cdot 3 \\
24 \cdot 2\end{array}$ & $\begin{array}{l}53.0 \\
55.9\end{array}$ & $\begin{array}{l}34.0 \\
15.5\end{array}$ & $\begin{array}{l}6 \cdot 7 \\
4 \cdot 4\end{array}$ & $\begin{array}{r}15828 \\
6,797\end{array}$ \\
\hline Total & $\mathbf{M}$ & $\begin{array}{r}7.5 \\
19.8\end{array}$ & $\begin{array}{l}51 \cdot 4 \\
51 \cdot 3\end{array}$ & $\begin{array}{l}34 \cdot 1 \\
21 \cdot 3\end{array}$ & $\begin{array}{l}7 \cdot 1 \\
7 \cdot 6\end{array}$ & $\begin{array}{l}34787 \\
37497\end{array}$ \\
\hline
\end{tabular}

T The sum of strata does not add up to the total because of missing values. 
of both sexes fell in the normal weight category (Quetelet's index 20 to 24.9, set as the reference category in further analyses). The women were more frequently underweight (overall, $20 \%$ of women and $8 \%$ of men had a Quetelet's index below 20 ), and, consequently, less frequently overweight $(21 \% v 34 \%$ for the 25 to 29.9 category). The proportion of grossly obese individuals was similar in the two sexes $(7.1 \%$ men, $7.6 \%$ women).

In table 1, the distribution of body mass index for both sexes is further presented in separate strata of age and other major covariates, such as educational attainment (showing a decreasing proportion of overweight subjects with higher education) and smoking habits (indicating that female but not male smokers tended to be lighter than never or ex-smokers).

The estimated overall prevalence of 17 selected diseases or groups of diseases in men, and the corresponding age-adjusted relative risks according to body mass index are reported in table 2 . The prevalence of diabetes was directly and strongly related to body weight: compared with normal weight individuals, the estimated relative risk was 0.8 for underweight, and rose to 1.5 for overweight and 2.7 for obese subjects. Other conditions directly related to self-reported measures of body weight were hypertension, myocardial infarction and other heart diseases, cholelithiasis, urolithiasis, renal insufficiency, and arthritis. Chronic respiratory disorders (bronchitis, emphysema or respiratory insufficiency and asthma) showed a $U$-shaped relation to measures of body weight, since their prevalence was elevated in both under- and over-weight individuals. Anaemias and gastroduodenal ulcer showed inverse relations with body weight, whereas no association was apparent with allergy, liver cirrhosis, and psychiatric or neurological disorders.

The data on the other two groups of diseases, ie, cancer and rheumatoid arthritis, were not considered

Table 2 Relative risk estimates (and 95\% confidence intervals) for the prevalence of selected diseases or groups of diseases according to body mass index among Italian males aged 15 or over. The 1983 National Health Survey.

\begin{tabular}{|c|c|c|c|c|c|}
\hline \multirow{2}{*}{$\begin{array}{l}\text { Disease or group of } \\
\text { diseases }\end{array}$} & \multirow{2}{*}{$\begin{array}{l}\text { Estimated overall } \\
\text { prevalence/1000 } \\
\text { males aged } 15 \text { or over }\end{array}$} & \multicolumn{4}{|c|}{ Relative risk estimatest among males with body mass index $\left(\mathrm{kg} / \mathrm{m}^{2}\right)$} \\
\hline & & $<20$ & $20-24 \cdot 9$ & $25-29 \cdot 9$ & $\geqslant 30$ \\
\hline Diabetes & $35 \cdot 7$ & $\begin{array}{l}0.77 \\
(0.56-1 \cdot 04)\end{array}$ & $1 \neq$ & $\begin{array}{l}1 \cdot 54 \\
(1 \cdot 35-1 \cdot 75)\end{array}$ & $\begin{array}{l}2 \cdot 69 \\
(2 \cdot 27-3 \cdot 18)\end{array}$ \\
\hline Hypertension & $67 \cdot 9$ & $\begin{array}{l}0.80 \\
(0.64-0.98)\end{array}$ & $1 \neq$ & $\begin{array}{l}1 \cdot 37 \\
(1 \cdot 25-1 \cdot 51)\end{array}$ & $\begin{array}{l}1 \cdot 74 \\
(1 \cdot 51-2 \cdot 00)\end{array}$ \\
\hline Myocardial infarction & $18 \cdot 0$ & $\begin{array}{l}1.06 \\
(0.74-1.52)\end{array}$ & $1 \neq$ & $\begin{array}{l}1 \cdot 16 \\
(0 \cdot 98-1 \cdot 33)\end{array}$ & $\begin{array}{l}1 \cdot 48 \\
1 \cdot 14-1 \cdot 92)\end{array}$ \\
\hline Other heart diseases & $39 \cdot 5$ & $\begin{array}{l}1 \cdot 19 \\
(0.95-1 \cdot 49)\end{array}$ & $1 \neq$ & $\begin{array}{l}1 \cdot 03 \\
(0 \cdot 90-1 \cdot 16)\end{array}$ & $\begin{array}{l}1 \cdot 72 \\
(1 \cdot 35-2 \cdot 19)\end{array}$ \\
\hline Haemorrhoids or varices & $42 \cdot 8$ & $\begin{array}{l}0.68 \\
(0.53-0.89)\end{array}$ & $1 \neq$ & $\begin{array}{l}1.09 \\
(0 \cdot 97-1 \cdot 22)\end{array}$ & $\begin{array}{l}1 \cdot 17 \\
(0 \cdot 96-1 \cdot 41)\end{array}$ \\
\hline Chronic bronchitis & $75 \cdot 9$ & $\begin{array}{l}1 \cdot 19 \\
(1 \cdot 00-1 \cdot 41)\end{array}$ & $1 \neq$ & $\begin{array}{l}1 \cdot 07 \\
(0 \cdot 98-1 \cdot 17)\end{array}$ & $\begin{array}{l}1 \cdot 24 \\
(1 \cdot 08-1 \cdot 43)\end{array}$ \\
\hline Emphysema or respiratory insufficiency & $25 \cdot 4$ & $\begin{array}{l}1 \cdot 48 \\
(1 \cdot 14-1 \cdot 91)\end{array}$ & $1 \neq$ & $\begin{array}{l}0.92 \\
(0 \cdot 79-1 \cdot 07)\end{array}$ & $\begin{array}{l}1 \cdot 37 \\
(1 \cdot 10-1 \cdot 71)\end{array}$ \\
\hline Bronchial asthma & $40 \cdot 4$ & $\begin{array}{l}1 \cdot 42 \\
(1 \cdot 15-1 \cdot 76)\end{array}$ & $1 \neq$ & $\begin{array}{l}1 \cdot 15 \\
(1 \cdot 02-1 \cdot 30)\end{array}$ & $\begin{array}{l}1 \cdot 70 \\
(1 \cdot 42-2 \cdot 02)\end{array}$ \\
\hline Allergy & $31 \cdot 9$ & $\begin{array}{l}0.84 \\
(0 \cdot 65-1.08)\end{array}$ & $1 \neq$ & $\begin{array}{l}0.95 \\
(0 \cdot 83-1 \cdot 08)\end{array}$ & $\begin{array}{l}1 \cdot 01 \\
(0 \cdot 79-1 \cdot 28)\end{array}$ \\
\hline Anaemias & $5 \cdot 4$ & $\begin{array}{l}1 \cdot 25 \\
(0 \cdot 75-2 \cdot 09)\end{array}$ & $1 \neq$ & $\begin{array}{l}0 \cdot 76 \\
(0 \cdot 55-1 \cdot 06)\end{array}$ & $\begin{array}{l}0.46 \\
(0.23-0.94)\end{array}$ \\
\hline Gastroduodenal ulcer & $65 \cdot 6$ & $\begin{array}{l}0.94 \\
(0 \cdot 78-1 \cdot 13)\end{array}$ & $1 \neq$ & $\begin{array}{l}0.88 \\
(0.80-0.97)\end{array}$ & $\begin{array}{l}0.83 \\
(0.71-0.98)\end{array}$ \\
\hline Cholelithiasis & $19 \cdot 3$ & $\begin{array}{l}0 \cdot 77 \\
(0 \cdot 52-1 \cdot 12)\end{array}$ & $1 \neq$ & $\begin{array}{l}1 \cdot 11 \\
(0 \cdot 94-1 \cdot 31)\end{array}$ & $\begin{array}{l}1 \cdot 24 \\
(0 \cdot 95-1 \cdot 61)\end{array}$ \\
\hline Liver cirrhosis & $5 \cdot 2$ & $\begin{array}{l}1.06 \\
(0.58-1 \cdot 95)\end{array}$ & $1 \neq$ & $\begin{array}{l}0 \cdot 87 \\
(0 \cdot 63-1 \cdot 21)\end{array}$ & $\begin{array}{l}1 \cdot 14 \\
(0 \cdot 69-1 \cdot 88)\end{array}$ \\
\hline Urolithiasis & $15 \cdot 4$. & $\begin{array}{l}0 \cdot 73 \\
(0 \cdot 46-1 \cdot 14)\end{array}$ & $1 \neq$ & $\begin{array}{l}1 \cdot 25 \\
(1 \cdot 04-1 \cdot 50)\end{array}$ & $\begin{array}{l}1 \cdot 58 \\
(1 \cdot 20-2 \cdot 08)\end{array}$ \\
\hline Renal insufficiency & $11 \cdot 5$ & $\begin{array}{l}0 \cdot 85 \\
(0 \cdot 55-1 \cdot 32)\end{array}$ & $1 \neq$ & $\begin{array}{l}0.78 \\
(0.62-0.97)\end{array}$ & $\begin{array}{l}1 \cdot 20 \\
(0.87-1 \cdot 67)\end{array}$ \\
\hline Arthritis & 168.9 & $\begin{array}{l}0.80 \\
(0.69-0.92)\end{array}$ & $1 \neq$ & $\begin{array}{l}1 \cdot 35 \\
(1 \cdot 27-1 \cdot 44)\end{array}$ & $\begin{array}{l}1 \cdot 36 \\
(1 \cdot 22-1 \cdot 51)\end{array}$ \\
\hline $\begin{array}{l}\text { Psychiatric and } \\
\text { neurological disorders }\end{array}$ & $45 \cdot 7$ & $\begin{array}{l}1 \cdot 23 \\
(1 \cdot 02-1 \cdot 48)\end{array}$ & $1 \neq$ & $\begin{array}{l}0.96 \\
(0.86-1.07)\end{array}$ & $\begin{array}{l}0.96 \\
(0 \cdot 79-1 \cdot 17)\end{array}$ \\
\hline
\end{tabular}


Body weight and the prevalence of chronic diseases

on account of their potential low reliability (for instance, it is possible that some subjects who had a cancer were not even informed of the nature of their disease) or widespread misclassification (ie, between rheumatoid and osteo arthritis).

The corresponding prevalences and risk estimates for women are reported in table 3 . The overall pattern was largely similar to that described in men, with direct relations between body weight and prevalence of diabetes, heart conditions, chronic respiratory diseases, cholelithiasis, kidney disease and arthritis, and inverse relations for anaemias and gastroduodenal ulcer.

Further allowance for education as an indicator of socioeconomic status and smoking had limited influence on the risk estimates presented. For instance, in obese men, the relative risk for diabetes changed from 2.69 to 2.88 and that for hypertension from 1.74 to 1.75 . In obese women, the changes in risk for diabetes after allowance for education and smoking were from 2.40 to 2.32, and for hypertension from 1.91 to 1.83 . It is possible that the modifying effect of these two covariates was in different directions, since smokers had elevated prevalences of several diseases, ${ }^{12}$ but, at least for women, smoking was more frequent among more educated subjects ${ }^{13}$ who, in turn, had a lower prevalence of most diseases. ${ }^{14}$

Table 4 gives stratified risk estimates for obese individuals in three separate age groups for the diseases whose overall prevalence was significantly elevated in the obese: for most conditions considered, the relative risks tended to be higher at a younger age and decreased steadily with advancing age.

\section{Discussion}

The findings of the 1983 Italian National Health Survey indicate that a substantial proportion of Italian men $(34 \%)$ and women $(21 \%)$ is overweight and over $7 \%$ of both sexes is grossly obese, on the basis

Table 3 Relative risk estimates (and 95\% confidence intervals) for the prevalence of selected diseases or groups of diseases according to body mass index among Italian females aged 15 or over. The 1983 National Health Survey.

\begin{tabular}{|c|c|c|c|c|c|}
\hline \multirow{2}{*}{$\begin{array}{l}\text { Disease or group of } \\
\text { diseases }\end{array}$} & \multirow{2}{*}{$\begin{array}{l}\text { Estimated overall } \\
\text { prevalence/ } 1000 \\
\text { females aged } 15 \text { or over }\end{array}$} & \multicolumn{4}{|c|}{ Relative risk estimatest among females with body mass index $\left(\mathrm{kg} / \mathrm{m}^{2}\right)$} \\
\hline & & $<20$ & $20-24 \cdot 9$ & $25-29 \cdot 9$ & $\geqslant 30$ \\
\hline Diabetes & $43 \cdot 8$ & $\begin{array}{l}0.71 \\
(0.59-0.78)\end{array}$ & $1 \neq$ & $\begin{array}{l}1.59 \\
(1.41-1 \cdot 79)\end{array}$ & $\begin{array}{l}2 \cdot 40 \\
(2 \cdot 09-2 \cdot 77)\end{array}$ \\
\hline Hypertension & $96 \cdot 5$ & $\begin{array}{l}0.78 \\
(0.69-0.89)\end{array}$ & $1 \neq$ & $\begin{array}{l}1.54 \\
(1.41-1.67)\end{array}$ & $\begin{array}{l}1 \cdot 91 \\
(1 \cdot 71-2 \cdot 13)\end{array}$ \\
\hline Myocardial infarction & $7 \cdot 3$ & $\begin{array}{l}1 \cdot 19 \\
(0 \cdot 83-1 \cdot 70)\end{array}$ & $1 \neq$ & $\begin{array}{l}0.92 \\
(0 \cdot 68-1 \cdot 23)\end{array}$ & $\begin{array}{l}1 \cdot 56 \\
1 \cdot 30-1 \cdot 87)\end{array}$ \\
\hline Other heart diseases & $57 \cdot 1$ & $\begin{array}{l}1 \cdot 11 \\
(0 \cdot 96-1 \cdot 28)\end{array}$ & $1 \neq$ & $\begin{array}{l}1 \cdot 28 \\
(1 \cdot 15-1 \cdot 43)\end{array}$ & $\begin{array}{l}1 \cdot 50 \\
(1 \cdot 30-1 \cdot 73)\end{array}$ \\
\hline Haemorrhoids or varices & $58 \cdot 8$ & $\begin{array}{l}0.77 \\
(0.67-0.89)\end{array}$ & $1 \neq$ & $\begin{array}{l}1 \cdot 36 \\
(1 \cdot 22-1 \cdot 50)\end{array}$ & $\begin{array}{l}1.46 \\
(1 \cdot 26-1 \cdot 69)\end{array}$ \\
\hline Chronic bronchitis & $35 \cdot 3$ & $\begin{array}{l}1 \cdot 11 \\
(0 \cdot 94-1 \cdot 32)\end{array}$ & $1 \neq$ & $\begin{array}{l}1.01 \\
(0 \cdot 88-1 \cdot 15)\end{array}$ & $\begin{array}{l}1 \cdot 43 \\
(1 \cdot 20-1 \cdot 70)\end{array}$ \\
\hline Emphysema or respiratory insufficiency & $13 \cdot 4$ & $\begin{array}{l}1 \cdot 63 \\
(1 \cdot 28-2 \cdot 06)\end{array}$ & $1 \neq$ & $\begin{array}{l}1 \cdot 07 \\
(0 \cdot 86-1 \cdot 34)\end{array}$ & $\begin{array}{l}1.40 \\
(1.06-1 \cdot 86)\end{array}$ \\
\hline Bronchial asthma & $24 \cdot 8$ & $\begin{array}{l}0.98 \\
(0 \cdot 79-1 \cdot 20)\end{array}$ & $1 \neq$ & $\begin{array}{l}1 \cdot 17 \\
(1 \cdot 00-1 \cdot 38)\end{array}$ & $\begin{array}{l}1.99 \\
(1.65-2 \cdot 40)\end{array}$ \\
\hline Allergy & $36 \cdot 2$ & $\begin{array}{l}0.96 \\
(0 \cdot 83-1 \cdot 11)\end{array}$ & $1 \neq$ & $\begin{array}{l}0.98 \\
(0 \cdot 85-1 \cdot 13)\end{array}$ & $\begin{array}{l}0.96 \\
(0 \cdot 77-1 \cdot 19)\end{array}$ \\
\hline Anaemias & $19 \cdot 9$ & $\begin{array}{l}1 \cdot 21 \\
(1 \cdot 01-1 \cdot 45)\end{array}$ & $1 \neq$ & $\begin{array}{l}0.78 \\
(0.64-0.95)\end{array}$ & $\begin{array}{l}0.65 \\
(0.47-0.90)\end{array}$ \\
\hline Gastroduodenal ulcer & 28.9 & $\begin{array}{l}1.06 \\
(0 \cdot 89-1 \cdot 25)\end{array}$ & $1 \neq$ & $\begin{array}{l}0.89 \\
(0.77-1.04)\end{array}$ & $\begin{array}{l}0.79 \\
(0.62-1 \cdot 00)\end{array}$ \\
\hline Cholelithiasis & $39 \cdot 3$ & $\begin{array}{l}0.83 \\
(0.70-0.98)\end{array}$ & $1 \neq$ & $\begin{array}{l}1 \cdot 31 \\
(1 \cdot 16-1 \cdot 48)\end{array}$ & $\begin{array}{l}1 \cdot 38 \\
(1 \cdot 16-1 \cdot 64)\end{array}$ \\
\hline Liver cirrhosis & $2 \cdot 0$ & $\begin{array}{l}0.81 \\
(0.39-1 \cdot 69)\end{array}$ & $1 \neq$ & $\begin{array}{l}1 \cdot 31 \\
(0 \cdot 79-2 \cdot 17)\end{array}$ & $\begin{array}{l}0.93 \\
(0 \cdot 41-2 \cdot 13)\end{array}$ \\
\hline Urolithiasis & $12 \cdot 2$ & $\begin{array}{l}0.85 \\
(0.63-1 \cdot 13)\end{array}$ & $1 \neq$ & $\begin{array}{l}1.62 \\
(1 \cdot 31-2 \cdot 00)\end{array}$ & $\begin{array}{l}1 \cdot 67 \\
(1 \cdot 25-2 \cdot 24)\end{array}$ \\
\hline Renal insufficiency & $12 \cdot 9$ & $\begin{array}{l}1 \cdot 38 \\
(1 \cdot 06-1 \cdot 81)\end{array}$ & $1 \neq$ & $\begin{array}{l}1 \cdot 34 \\
(1 \cdot 07-1 \cdot 68)\end{array}$ & $\begin{array}{l}2 \cdot 17 \\
(1 \cdot 67-2 \cdot 82)\end{array}$ \\
\hline Arthritis & $214 \cdot 7$ & $\begin{array}{l}0.75 \\
(0.69-0.81)\end{array}$ & $1 \neq$ & $\begin{array}{l}1.35 \\
(1 \cdot 27-1 \cdot 44)\end{array}$ & $\begin{array}{l}1.56 \\
(1 \cdot 42-1 \cdot 70)\end{array}$ \\
\hline $\begin{array}{l}\text { Psychiatric and } \\
\text { neurological disorders }\end{array}$ & $72 \cdot 8$ & $\begin{array}{l}1.09 \\
(0 \cdot 98-1 \cdot 22)\end{array}$ & $1 \neq$ & $\begin{array}{l}1.09 \\
(0 \cdot 99-1 \cdot 21)\end{array}$ & $\begin{array}{l}1 \cdot 13 \\
(0 \cdot 98-1 \cdot 30)\end{array}$ \\
\hline
\end{tabular}

† Mantel-Haenszel estimates adjusted for age in decades.

$\neq$ Reference category. 
Table 4 Sex- and age-specific relative risk estimates of selected diseases in obese individuals (body mass index $\geqslant 30$ ) $v$ average weight ones (body mass index 20 to 24.9). Data from the National Health Survey conducted by the Central Institute of Statistics, Italy, 1983.

\begin{tabular}{|c|c|c|c|c|}
\hline \multirow{2}{*}{$\begin{array}{l}\text { Disease or group of } \\
\text { diseases }\end{array}$} & \multirow{2}{*}{$\operatorname{Sex}$} & \multicolumn{3}{|l|}{ Age group } \\
\hline & & $15-44$ & $45-64$ & $\geqslant 65$ \\
\hline Diabetes & $\begin{array}{c}\mathbf{M} \\
\mathbf{F}\end{array}$ & $\begin{array}{l}2 \cdot 61 \\
4 \cdot 16\end{array}$ & $\begin{array}{l}3 \cdot 11 \\
3 \cdot 14\end{array}$ & $\begin{array}{l}2 \cdot 21 \\
1 \cdot 81\end{array}$ \\
\hline Hypertension & $\begin{array}{c}\mathbf{M} \\
\mathbf{F}\end{array}$ & $\begin{array}{l}3 \cdot 43 \\
2 \cdot 46\end{array}$ & $\begin{array}{l}2 \cdot 10 \\
2 \cdot 48\end{array}$ & $\begin{array}{l}1 \cdot 10 \\
1 \cdot 36\end{array}$ \\
\hline Myocardial infarction & $\begin{array}{c}\mathbf{M} \\
\mathbf{F}\end{array}$ & $\begin{array}{c}2.48 \\
-\end{array}$ & $\begin{array}{l}1.46 \\
2.47\end{array}$ & $\begin{array}{l}1.46 \\
1.11\end{array}$ \\
\hline Other heart diseases & $\begin{array}{c}\mathbf{M} \\
\mathbf{F}\end{array}$ & $\begin{array}{l}1 \cdot 17 \\
2 \cdot 02\end{array}$ & $\begin{array}{l}1 \cdot 81 \\
1 \cdot 78\end{array}$ & $\begin{array}{l}1 \cdot 40 \\
1 \cdot 25\end{array}$ \\
\hline $\begin{array}{l}\text { Emphysema or respiratory } \\
\text { insufficiency }\end{array}$ & $\begin{array}{c}\mathbf{M} \\
\mathbf{F}\end{array}$ & $\begin{array}{l}1.09 \\
2.38\end{array}$ & $\begin{array}{l}1 \cdot 86 \\
2 \cdot 17\end{array}$ & $\begin{array}{l}0.86 \\
0.83\end{array}$ \\
\hline Cholelithiasis & $\begin{array}{c}\mathbf{M} \\
\mathbf{F}\end{array}$ & $\begin{array}{l}2.07 \\
1.53\end{array}$ & $\begin{array}{l}1.27 \\
1.74\end{array}$ & $\begin{array}{l}0.94 \\
0.95\end{array}$ \\
\hline Urolithiasis & $\begin{array}{c}\mathbf{M} \\
\mathbf{F}\end{array}$ & $\begin{array}{l}2 \cdot 53 \\
1.46\end{array}$ & $\begin{array}{l}1.23 \\
1.85\end{array}$ & $\begin{array}{l}2 \cdot 06 \\
1 \cdot 49\end{array}$ \\
\hline
\end{tabular}

of self reported measures of body weight and standard cut-off points of Quetelet's index adopted in epidemiological studies. ${ }^{1516}$ Using the same criteria, a recent Canadian Survey ${ }^{15}$ estimated that $31.3 \%$ of population aged 20 to 69 was overweight and $6.1 \%$ obese. The American National Health and Nutrition Examination Survey ${ }^{17}$ found that $26 \%$ of US adults were overweight, using a body mass index of 27.8 or greater for men and 27.3 for women to define overweight.

In this study, obesity was associated with an elevated prevalence of a large number of important chronic conditions, including diabetes, heart diseases, respiratory conditions, cholelithiasis, kidney disease. ${ }^{5}$ and arthritis. For most of these diseases, the risk estimates for the overweight group were above unity, too, and the overall evidence indicates that even a less severe degree of overweight implies considerable health risks. Using the same cut-off points for the two sexes, the risk estimates were similar, suggesting that, for the diseases considered, overweight and obesity present similar risks to men and women.

Some of these findings (ie, the positive relations of overweight to diabetes, heart conditions, and digestive diseases) are widely recognised, since they have been repeatedly described in cohort studies chiefly on the basis of mortality statistics. ${ }^{1-5}$ There are also a few cross-sectional studies, such as the American National Health and Nutrition Examination Survey ${ }^{17}$ which showed elevated prevalences of hypertension, hypercholesterolaemia, and diabetes in overweight individuals. The estimated relative risks in these Italian data were similar to those reported from the American survey (ie, an overall relative risk of 2.9 for diabetes), and in both studies the risk estimates were higher in the younger age groups.
The Dutch Health Interview Surveys ${ }^{18}$ showed that, in men, severe overweight was associated with hypertension, especially in younger middle age, whereas in women severe overweight was positively related to hypertension, diabetes, varicose veins, asthma/bronchitis, and haemorrhoids. In that study, too, subjects who were moderately overweight (body mass index 25-29.9) tended to have a relative risk above unity for most diseases considered, and hence intermediate risk between normal weight individuals and obese ones.

Further, a survey based on four Dutch general practices $^{16}$ and a study from the US Health Insurance Experiment $^{19}$ indicated that subjective health complaints were more common in overweight subjects, particularly in women, ${ }^{16}$ and that the General Health Index was slightly poorer as weight increased. ${ }^{19}$

Other studies showed that the relation of overweight to disease was lower at older ages. For instance, in the elderly, high body mass index was unrelated to mortality in a cohort study from Finland. ${ }^{20}$

Other findings of this study are more difficult to interpret. For instance, all three respiratory conditions considered (chronic bronchitis, emphysema or respiratory insufficiency, and bronchial asthma) showed a "U" shaped relation to body weight, chiefly in men. It is possible that the elevated risks in underweight individuals are due to higher smoking rates, since smoking is related to respiratory diseases. ${ }^{21}$ However, underweight rates were reduced among Italian male smokers, ${ }^{11}$ and hence allowance for smoking did not reduce the estimated relative risk of lung emphysema in underweight men (adjusted $\mathrm{RR}=1.54,95 \% \mathrm{CI}=1.19-1.99$ ), nor for chronic bronchitis (adjusted $\mathrm{RR}=1.25,95 \% \quad \mathrm{CI}=1.05-$ 1.49). With regard to the elevated risk of respiratory conditions in the obese, it is known that gross obesity is related to hypoventilation, respiratory insufficiency, and cor pulmonale (Pickwickian syndrome), but there is no easy explanation for the elevated risks of chronic bronchitis or bronchial asthma.

It is possible that these apparent associations were due to misclassification bias, since the interviews were conducted by non medically trained civil servants who might not have been able to distinguish between the mucous hypersecretion of chronic bronchitis or the respiratory distress of bronchial asthma and the respiratory insufficiency of lung emphysema. ${ }^{22}$ Likewise, there is to our knowledge little support from previous studies on the positive associations between body weight and urolithiasis and renal insufficiency that emerged in this survey.

Besides reliability of diagnosis, the other major problem in the interpretation of this dataset pertains 
to validation of data on height and weight, which are based on self-reporting only, in the absence of any objective measurement. Although a systematic tendency towards overestimating height and underestimating weight is known, self-reported measures show generally very high correlations with actual ones. ${ }^{23}{ }^{24}$ Further, there is little $a$ priori reason to assume a differential reporting of height and weight on the basis of health conditions. On the other hand, the importance of this study should be considered in the light of its large dataset, representative of the general Italian population in terms of distribution for age, sex, and region of residence. Further, since less than $7 \%$ of the households originally selected had to be substituted, and direct interview was obtained from over $90 \%$ of the subjects identified, it is unlikely that the findings are appreciably affected by selection bias.

In conclusion, therefore, the limitations and uncertainties of some of the information collected can hardly, in our opinion, obscure the major findings of a widespread and substantial impact of overweight not only on mortality, but also on morbidity from different serious chronic conditions. Further, it is particularly worrying, in terms of public health and economic implications, that the relative risks of obesity for most diseases were higher in younger and middle aged than in older individuals.

This work was conducted within the framework of the CNR (Italian National Research Council) Applied Projects "Oncology" (contract no. 85.02209.44) and "Preventive and Rehabilitative Medicine" (contracts no. 85.00487.56 and 85.00549.56). The generous contribution of the Italian League against Tumours, Milan, Italy, is gratefully acknowledged. Data processing and analysis was performed using the computing facilities of the Inter-University Consortium of Lombardy for Automatic Data Processing (CILEA). We thank Ms Judy Baggott, Ms Gigliola Brambilla Pisoni, and the GA Pfeiffer Memorial Library for editorial assistance.

Address all correspondence to Dr Carlo La Vecchia, Istituto di Ricerche Farmacologiche "Mario Negri", Via Eritrea, 62-20157 Milan, Italy.

\section{References}

${ }^{1}$ Lew EA, Garfinkel L. Variations in mortality by weight among 750,000 men and women. J Chron Dis 1979; 32: 563-76.

2 Garrison RJ, Castelli WP. Weight and thirty-year mortality of men in the Framingham study. Ann Int Med 1985; 103: 1006-9.

${ }^{3}$ Feinleib M. Epidemiology of obesity in relation to health hazards. Ann Intern Med 1985; 103: 1019-24.
${ }^{4}$ Lew EA. Mortality and weight: Insured lives and the American Cancer Society studies. Ann Intern Med 1985; 103: 1024-9.

5 Garfinkel L. Overweight and mortality. Cancer 1986; 58: 1826-9.

${ }^{6}$ Istituto Centrale di Statistica (ISTAT). Indagine statistica sulle condizioni di salute della popolazione e sul ricorso ai servizi sanitari-1983. Primi risultati. Roma: Notiziario ISTAT, 1984; 4: no. 8.

${ }^{7}$ La Vecchia C, Decarli A, Pagano R. Prevalence of cigarette smoking among subsequent cohorts of Italian males and females. Prev Med 1986; 15: 606-13.

${ }^{8}$ Benn RT. Some mathematical properties of weight-forheight indices used as measures of adiposity. $B r J$ Prev Soc Med 1971; 25: 42-50.

9 Breslow NE, Day NE. Statistical methods in cancer research. IARC Scientific Publications Vol. 32, Lyon: IARC 1980.

${ }^{10}$ Mantel N, Haenszel W. Statistical aspects of the analysis of data from retrospective studies of disease. $J$ Natl Cancer Inst 1959; 22: 719-48.

11 Pagano R, Negri E, Decarli A, La Vecchia C. Smoking and weight in the 1983 Italian National Health Survey. Int J Obes, 1987; 11: 333-8.

12 La Vecchia C, Pagano R, Negri E, Decarli A. Smoking and prevalence of disease in the 1983 Italian National Health Survey. Int $J$ Epidemiol; in press.

${ }^{13}$ La Vecchia C, Decarli A, Pagano R. Education and prevalence of smoking in Italian men and women. Int J Epidemiol 1986; 15: 279.

14 La Vecchia C, Negri E, Pagano R, Decarli A. Education, prevalence of disease and frequency of health care utilization. The 1983 Italian National Health Survey. $J$ Epidemiol Commun Health 1987; 41: 161-5.

15 Millar WJ. Distribution of body weight and height: Comparison of estimates based on self-reported and observed measures. J Epidemiol Community Health 1986; 40: 319-23.

${ }^{16}$ Seidell JC, Bakx KC, Deurenberg P, et al. The relation between overweight and subjective health according to age, social class, slimming behavior and smoking habits in Dutch adults. Am J Public Health 1986; 76: 1410-15.

17 Van Itallie TB. Health implications of overweight and obesity in the United States. Ann Intern Med 1985; 103: 983-8.

${ }^{18}$ Seidell JC, de Groot LCPGM, van Sonsbeek JLA, et al. Associations of moderate and severe overweight with self-reported illness and medical care in Dutch adults. $\mathrm{Am}$ J Public Health 1986; 76: 264-9.

${ }^{19}$ Stewart AL, Brook RH. Effects of being overweight. Am J Public Health 1983; 73: 171-8.

${ }^{20}$ Mattila K, Haavisto M, Rajala S. Body mass index and mortality in the elderly. $\mathrm{Br}$ Med $J$ 1986; 292: 867-8.

${ }^{21}$ US Office on Smoking and Health. The health consequences of smoking. Chronic obstructive lung disease. A report of the Surgeon General. Washington, D.C.: GPO, 1984.

22 Peto $\mathbf{R}$, Speizer FE, Cochrane AL, et al. The relevance in adults of air-flow obstruction, but not hypersecretion, to mortality from chronic lung disease. Results from 20 years of prospective observation. Am Rev Respir Dis 1983; 128: 491-500.

${ }^{23}$ Stark O, Atkins E, Wolff OH, Douglas JWB. Longitudinal study of obesity in the National Survey of Health and Development. Br Med J 1981; 283: 13-7.

${ }^{24}$ Stewart AW, Jackson RT, Ford MA, Beaglehole R. Underestimation of relative weight by use of self-reported height and weight. Am J Epidemiol 1987; 125: 122-6. 